\title{
S5ynthesis
}

International Scientific Conference of IT and Business-Related Research

\section{RISK ASSESSMENT METHODOLOGY IN THE USE OF MOBILE PHONES}

\section{METODOLOGIJA ZA PROCENU RIZIKA PRILIKOM KORIŠĆENJA MOBILNIH TELEFONA}

\author{
Ana Bašić1 ${ }^{1}$ Predrag Popović ${ }^{2}$ \\ ${ }^{1}$ Singidunum University, Belgrade, Republic of Serbia \\ ${ }^{2}$ Vinča Institute of Nuclear Sciences, Belgrade, Republic of Serbia
}

\begin{abstract}
:
As regards health, ethical and social aspects, the use of radio and telecommunication terminal equipment implies the existence of a risk to the users of such equipment. An additional problem is that there is still no general standard for radio and telecommunication terminal equipment that could define principles for the design of this type of equipment with an emphasis on risk assessment and risk reduction. Based on the new standard for risk assessment in the field of machinery, EN ISO 12100 , this paper proposes methodology for risk assessment in the use of mobile phones, which is viewed as a typical representative of radio and telecommunication terminal equipment. Based on the proposed methodology, the paper presents the research results of risk assessment that may arise in the use of mobile phones by children. The aim of the research is to define all possible risks in the use of mobile phones and their ranking through implementation the defined methodology.
\end{abstract}

\section{Key words:}

RTTE Directive, EN ISO 12100, risk assessment, mobile phone, methodology.

\section{INTRODUCTION}

Risk assessment and risk management in technical systems both imply very important economic and general social problems. Successful solving of the issues of risk management is possible if the phenomena and management methods are wellknown. The progress in the product conformity procedure has been made by integrating the requirements for technical products safety into the process of designing, where risk levels are preventively analyzed and quantified with the aim of determining the scope of necessary safety systems (Đapić at al., 2012). The New Approach directives and some harmonized standards explicitly specify the risk assessment procedure, and if the risk assessment is not stated within a directive, it can be requested by a standard related to the directive.

For radio and telecommunication terminal equipment (R\&TT equipment), there is still no general standard that could define the principles for designing this type of equipment, with the emphasis on risk assessment and risk reduction.

The Directive 1999/5/EC of the European Parliament and Council of March 9, 1999 on radio and telecommunication terminal equipment (the R\&TTE directive) has been transposed into technical legislation of the Republic of Serbia by bringing of the Rulebook on Radio and Telecommunication Terminal Equipment (Official Gazette RS, No. 11/12; Bašić \& Popović, 2013). The Rulebook on R\&TT equipment came into effect on February 22, 2012, and its application started on June 1, 2012.

\section{Apstrakt:}

Posmatrano sa zdravstvenog, etičkog i socijalnog aspekta upotreba radio i telekomunikacione terminalne opreme podrazumeva postojanje niza rizika po korisnike ove vrste opreme. Dodatni problem predstavlja što za radio i telekomunikacionu terminalnu opremu još uvek ne postoji opšti standard koji definiše principe za projektovanje ove vrste opreme sa akcentom na oceni i smanjenju rizika. Na osnovu novog standarda za ocenu rizika iz područja mašina, EN ISO 12100, u ovom radu prikazan je predlog metodologije za procenu rizika pri upotrebi mobilnog telefona, koji je uzet kao tipičan predstavnik radio i telekomunikacione terminalne opreme. Na osnovu predložene metodologije, u radu su prikazani rezultati istraživanja procene rizika koji mogu da nastanu pri upotrebi mobilnog telefona kod dece. Cilj sprovedenog istraživanja predstavlja definisanje svih mogućih rizika pri upotrebi mobilnog telefona i njihovo rangiranje primenom definisane metodologije.

\section{Ključne reči:}

RTTE direktiva, EN ISO 12100, ocena rizika, mobilni telefon, metodologija.

On the basis of a new standard for risk assessment in the field of machinery, the EN ISO 12100, the paper provides a proposal of the methodology for risk assessment in the use of mobile phones, as the typical R\&TT equipment representative. The paper defines almost fifty different situations for which there is a certain probability of occurrence during mobile phone usage. Special emphasis is placed on the risks that may occur during mobile phone use by children. These risks are specifically singled out and ranked by applying the proposed methodology. Finally, the paper lists proposals for reducing the existing risks, with the aim to protect the overall customer health and safety.

\section{THE IMPACT OF MOBILE PHONES ON USER HEALTH AND SAFETY}

\section{USE OF MOBILE PHONES}

According to the data of the Statistical Office of the Republic of Serbia, there are $86.9 \%$ homes in the Republic of Serbia that own mobile phones (Republic Institute for Statistics, 2013). By observing the data in the three preceding years, it is obvious that the number of mobile phone users is continually growing. With respect to 2012, the number of people using mobile phones has increased by over 30000 .

By analyzing the data of the Statistical Office of the Republic of Serbia related to mobile phone use according to users' gender 
and age, it has been discovered that there were no data related to mobile phone usage by customers under 16 . We are witnessing the fact that the number of these users is not negligible, so that the statistics on the number of users according to their age have not provided realistic results.

\section{THE IMPACT OF MOBILE PHONES ON USERS' HEALTH}

Mobile phones create electromagnetic field which, under certain conditions, can be detrimental to health. Numerous changes in the reproductive, brain, osteo-cartilage and other tissues have been observed after their exposure to electromagnetic radiation.

The quantity of absorbed energy and distribution of energy density in the subject exposed to the action of electromagnetic field is the function of electric field strength and magnetic induction in the subject itself. The resulting distribution of energy can be described by the term specific absorption - SAR (Specific Absorption Rate), defined as the speed of accretion of the energy absorbed according to the unit of mass (Krstić et al., 2004). SAR is a sequentially dependent quantity and has the maximum value at the resonant frequency which, for humans, is of the value of $100 \mathrm{MHz}$ [4]. The limit value for SAR is $2 \mathrm{~W} / \mathrm{kg}$.

In essence, two types of electromagnetic radiation are distinguished - thermal and non-thermal. Thermal effects have been rather well studied and they cover philosophical effects, effects of change of behaviour, etc. On the other hand, there are contradictory opinions regarding the existence of non-thermal effects, so that further research in this area is expected to prove or deny validation of these effects.

Numerous research has shown that mobile phone electromagnetic radiation penetrates the child's head much more than the head of an adult, which is particularly visible through thermal effects these devices can cause (Kumar et al., 2010; Bhat et al., 2013). Various international institutions have pointed out this problem, so that in some countries parents have been recommended not to let their children use mobile phones or to limit the use to 10 minutes of communication on a daily basis. It is interesting that mobile phone is the only electric device where there is not even a preventive warning to be kept away from the reach of children (Bašić \& Viduka, 2014).

\section{ETICAL ASPECT OF MOBILE PHONE USE}

The basic question posed in the analysis of the ethical aspects of mobile phone use by children is: where is the limit determining whether something is moral or not? Establishing this limit is a great challenge and to some extent the issue of personal decision, personal understanding of the given situation, needs, interests and motives, as well as the issue of own moral integrity, but also the issue of cultural heritage, expectations and pressure coming from the environment (Dragin et al., 2013).

The technological advancement has not altered the basic ethical rules, but new technologies have caused new approaches to non-ethical behavior. The issues of privacy infringement, intellectual property piracy and spreading of false information have gained larger dimensions on the Internet. The ease of obtaining and sharing personal information on the Internet presents a great problem. In case the mobile phone user is a child, there is great probability that he/she will execute certain operations over the Internet (downloading unknown applications, visiting unreliable web locations, irregular password change, etc.), which can jeopardize the child's safety.

\section{SOCAL ASPECTS OF MOBILE PHONE USE}

Exploitation of children by way of information-communication technologies (ICT) represents a social issue. Not only children and the young face the problem of ICT exploitation, but also their parents, teachers and other experts working with children, as well as the entire society, including government authorities and media. Any prevention of exploitation of children on the Internet contrbutes to increasing the capacity and possibilities of realizing children rights in accordance with the UN Convention on the rights of the child by improving the child protection system from all modes of abuse, neglect and violence over children.

Exploitation of children on the Internet is also called virtual or electronic violence. Electronic violence is generally characterized by sending or publishing insulting or violent contents by using the Internet available via computers, mobile phones or other electronic communication means.

\section{STRATEGIC FRAMEWORK FOR INCREASING INFORMATION SAFETY LEVEL}

The strategy of information society development in the Republic of Serbia until 2020 contains provisions on information safety where the following priorities are determined: improving legal and institutional framework for information safety, protection of critical infrastructure, fighting high technological criminal, scientific-research and development work in the field of information safety. It is necessary to bring regulations in the field of information safety by which the standards of information safety will be regulated, as well as the fields of information safety and competencies and tasks of specific institutions in this field.

Raising the information safety level for children has been additionally regulated by the National Action Plan for Children, defining the general state policy related to children, for the period until 2015, as well as by the National Strategy for Safeguarding Children from Violence, for the period from 2008 to 2015.

\section{PROPOSAL OF THE METHODOLOGY FOR RISK ASSESSMENT IN THE USE OF MOBILE PHONES}

Each mobile phone manufacturer is obliged, in accordance with the risk reducing methodology defined by EN ISO 12100 standards, to specify in detail safety information within the framework of the instructions for the use of the device, and inform the customer of all residual risks (EN ISO 12100, 2010). Disobeying of the safety warnings and regulations can cause serious injuries, property damage or death.

On the basis of the risk assessment and reduction methodology given in standard EN ISO 12100, as well as the proposal for the R\&TT equipment and general procedure for risk assessment and reduction given in (Bašić \& Popović, 2014), this chapter provides the methodology proposal for risk assessment and reduction in the mobile phone usage.

\section{METHODOLOGY SCOPE}

The procedure defined in this chapter defines the guidelines for risk assessment and determines the protection in mobile phone use. The procedure can be applied in the following cases:

- In the process of preparing the documentation, by which permit is obtained from competent state authorities or foreign authorities stating that the equipment can be 
used in accordance with the RTTE Directive requirements;

- in assessing the risk level for risky operations such as: mobile phone use in the vicinity of massive antenna facilities, mobile phone use while driving, mobile phone use in the open space during thunder storms, etc.;

- in assessing the risk levels in the device use by different customer categories such as children, pregnant women, those with heart disease and pacemakers, etc.;

- in selecting personal protective devices.

\section{RESPONSIBILITIES}

Application of the risk assessment methodology described by this procedure is the responsibility of manufacturers, mobile operators, users, as well as all socially responsible enterprises.

\section{PROCEDURE DESCRIPTION}

The risk assessment methodology in mobile phone usage covers consideration of all risk factors involved, also including the unpredicted parameters. The methodology has to provide answers to questions, such as: what are the risks in using mobile phones; what incidents can be expected; what measures can be taken; what are the possible consequences; what the probability of hazardous event occurrence is; the costs- alternative technologies, etc. The risk assessment is done in five steps, as follows: determining the intended equipment application, i.e. the functional analysis; identifying risks, various situations and different events; risk assessment; risk evaluation and the analysis of risk reduction measures.

Functional Analysis. The commencement of the functional analysis requires gathering of a series of information, such as:

- Information related to mobile phone description (technical specification, description of possible users, instructions for use);

- Information related to applicable regulations, relevant standards, recommendations and other documents with the data on safety relating to mobile phones;

- Information related to the experience in use (information on accidents, incidents or malfunctions, data on health hazards, users' experience with similar type of R\&TT equipment).

On the basis of the general procedure for risk assessment and reduction for products that do not fulfill the basic requirements of the RTTE Directive given in [10], the functional analysis implies the analysis of the intended use, as well as mobile phone possible abuse. The precise defining of the equipment entails determining the following factors:

- Limits of use (frequency band, maximum radiated power, type of antenna, emission class, types of connections, type of power supply, etc.);

- Different modes of the equipment operation as well as the procedure for interventions in case of equipment malfunction;

- Type of equipment use (industrial use, home use, personal use, etc.);

- Type of the equipment user;

- Spatial and climate limitations in using the equipment;

- Equipment time limitations (life limits of the equipment or some of its components, recommended servicing intervals, etc.).

Identification of Hazards. Depending on the type of R\&TT equipment, there are several hazards. The identified hazards can be of mechanical, electrical, thermal nature. Also, when using some R\&TT equipment, hazards can occur from too loud noise, vibrations or electromagnetic radiation. In the use of R\&TT equipment, there hazard of occurrence of detrimental interferences is often identified which can significantly jeopardize radio-navigation and radio-communication services. There are numerous hazards that can be identified in the course of irregular R\&TT equipment use (e.g. disallowed stay in the vicinity of massive antenna facilities, mobile phone use during driving, etc.). Also, it is necessary to mention the occurrence of electronic violence, as well as increasingly frequent hazards occurring in the use of information-communication technologies (ICT) made available by the R\&TT equipment.

In order to identify the hazards, it is necessary to identify the manner of the equipment operation and the tasks to be performed by persons in interaction with the equipment. It is also necessary to consider both normal and irregular equipment operations, as well as reasonably foreseeable misuse of the equipment. Table 1 provides the list of possible hazards in the mobile phone use.

\begin{tabular}{|c|c|c|}
\hline No & Hazard Type & Hazard \\
\hline 1 & Mechanical & $\begin{array}{l}\text { Mechanical damage of the device and its } \\
\text { additional equipment, small parts of the } \\
\text { device and additional equipment }\end{array}$ \\
\hline 2 & Electrical & $\begin{array}{l}\text { Damaged supply cables, damaged plugs, } \\
\text { loose electrical receptacles }\end{array}$ \\
\hline 3 & Thermal & $\begin{array}{l}\text { Exposing the device to extreme tempera- } \\
\text { tures }\end{array}$ \\
\hline 4 & Noise & Exposing ears to very high tones \\
\hline 5 & Radiation & Electromagnetic radiation \\
\hline 6 & $\begin{array}{l}\text { Composition } \\
\text { of the materi- } \\
\text { als used }\end{array}$ & $\begin{array}{l}\text { Incorrect storing of the device and its ad- } \\
\text { ditional equipment }\end{array}$ \\
\hline 7 & $\begin{array}{l}\text { Hazards } \\
\text { caused by } \\
\text { the environ- } \\
\text { ment in which } \\
\text { mobile phone } \\
\text { is used }\end{array}$ & $\begin{array}{l}\text { Mobile phone use in the open space dur- } \\
\text { ing thunder storm, exposing the device to } \\
\text { high pressure, use of the device in the area } \\
\text { with high dust concentration, use in an } \\
\text { airplane, device use while driving, submit- } \\
\text { ting the device to thick smoke and fumes }\end{array}$ \\
\hline 8 & $\begin{array}{l}\text { Hazards } \\
\text { caused by us- } \\
\text { ing ICT }\end{array}$ & Electronic violence \\
\hline
\end{tabular}

Table 1. Identification of potential hazards in mobile phone use.

Identification of Subjects Exposed to Hazards. Table 2 defines possible equipment users, i.e. mobile phone users.

\begin{tabular}{ccc}
\hline No & User Type & User Category \\
\hline 1 & Very vulnerable users & Children \\
\hline 2 & Vulnerable & Pregnant women, patients with \\
users & pacemaker \\
\hline 3 & $\begin{array}{c}\text { Other } \\
\text { users }\end{array}$ & $\begin{array}{c}\text { Users not belonging to user } \\
\text { type 1 and 2 }\end{array}$ \\
\hline
\end{tabular}

Table 2. Identification of subjects exposed to hazards

Description of Hazard Impact on the Subject + Injury/ Damage. On the basis of the safety information provided by the manufacturer, a list has been composed in Table 3 with scenarios describing how hazards influence the subject, stating also injuries/damage occurring on such occasion. The basis for composing Table 3 has been the instruction for use of the mobile 
phone GT-I9505 (Galaxy S4), produced by Samsung Electronics. Due to the limitations of the scope of this paper, Table 3 is not shown in its entirety.

\begin{tabular}{cll}
\hline No & \multicolumn{1}{c}{ Injury Scenario } & \multicolumn{1}{c}{ Injury/Damage } \\
\hline 1 & $\begin{array}{l}\text { The user uses damaged supply } \\
\text { cables, damaged plugs or loose } \\
\text { electric receptacles. }\end{array}$ & Electric shock, fire \\
\hline 2 & $\begin{array}{l}\text { The user touches supply cable } \\
\text { with wet hands or switches off the } \\
\text { charger by pulling the cable }\end{array}$ & Electric shock \\
\hline 3 & $\begin{array}{l}\text { The user uses the device outdoors } \\
\text { during thunder storm. }\end{array}$ & $\begin{array}{l}\text { Electric shock, de- } \\
\text { vice malfunction }\end{array}$ \\
\hline$\ldots$ & \multicolumn{2}{l}{$\begin{array}{l}\text { Obstruction of } \\
\text { pacemaker opera- } \\
\text { tion, }\end{array}$} \\
& $\begin{array}{l}\text { Obstructed hearing } \\
\text { aid operation } \\
\text { pacemaker or in vicinity of the } \\
\text { hearing aid. }\end{array}$ &
\end{tabular}

The user uses the device in poten-

tially explosive environments.

Note 1: In potentially explosive environments, battery should not be removed but the device should only be switched off.

$43 \quad$ Note 2: The device should be designed so as to satisfy the basic requirements of the Directive on equipment and protective systems intended for use in potentially explosive atmospheres (ATEX Directive 94/9/EC)

The user keeps the device in the vicinity of a magnetic field.

Note 1: Magnetic fields can damage the card with magnetic stripes,

44 including credit cards, phone cards and plane passes.

Note 2: The device should be designed so as to satisfy the basic requirements of the EMC Directive 2004/108/EC

The user takes over unknown applications, visits non-reliable web locations, does not delete doubt-

45 ful messages or e-messages from unknown senders, does not change his/her password regularly, does not deactivate wireless functions when not in use, etc.

Explosion, fire

Device failure, battery discharge

Damage or loss of data, all forms of electronic violence

The user carries or uses the device at the distance less than $1,5 \mathrm{~cm}$ away from the body.

$46 \quad$ Note 1: It is necessary for the user to check if the device fulfills the requirements regarding national SAR limit values of $2 \mathrm{~W} / \mathrm{kg}$

The user leaves the device and its additional electronic equipment or battery together with other home waste materials.

Note: In order to prevent jeopardizing the environment and health of people, it is necessary that the device, battery and additional electronic equipment be separated from other scrap and to be recycled for the purpose of promoting the renewed use of material resources.

Increased level of electromagnetic radiation

Jeopardizing environment and people's health
Determining Hazard Level, Injury Degree. In the course of risk assessment, it is necessary to determine severity of possible damage and probability of damage occurrence. Risk severity is defined through injury/damage to user's health or through device damage, and is given in Table 4.

\begin{tabular}{cll}
\hline Level & Risk severity & \multicolumn{1}{c}{ Injury/damage/harm } \\
\hline 4 & Catastrophic & $\begin{array}{l}\text { Death or complete obstruction of } \\
\text { radio-communication system. }\end{array}$ \\
\hline 3 & High & $\begin{array}{l}\text { Severe user's injury or major harm } \\
\text { of radio-communication system, } \\
\text { major device harm. }\end{array}$ \\
\hline 2 & Small & $\begin{array}{l}\text { Small user injury, small damage of } \\
\text { radio-communication system, small } \\
\text { device damage }\end{array}$ \\
\hline 1 & Neglectable & $\begin{array}{l}\text { Very small user injury, very small } \\
\text { damage of radio-communication } \\
\text { system, very small device damage }\end{array}$ \\
\hline
\end{tabular}

Table 4. Defining the level of damage/harm, injury degree.

Level 4 risks are the risks the severity of which is highest and due to which major irreversible consequences occur (e.g. death due to electric shock or fire). Level 3 risks are the risks of high severity due to which significant negative consequences occur that can be eliminated in longer time periods by way of special interventions entailing significant effort, and which can be irreversible in case when certain interventions are not applied (e.g. risk from electromagnetic radiation, risk of suffocation by small items, risk of hearing or eyesight damage, etc.). Level 2 risks, i.e. the risks of small severity, cause negative consequences that can be eliminated in a certain time period with the use of special instructions/consultations (e.g. loss of data, irritation on user's skin, etc.). The least severity risks are those of Level 1 that cause negative consequences which can usually be fully removed within the short time period without special instructions.

Determining Probability of Damage/Injury Occurrence. Frequency of risk occurrence is shown in Table 5. It is estimated for each severity level and expressed qualitatively, as: frequent, probable, occasional, rare and improbable.

\begin{tabular}{lll}
\hline $\begin{array}{c}\text { Risk fre- } \\
\text { quency }\end{array}$ & \multicolumn{1}{c}{ Description } & \multicolumn{1}{c}{ Note } \\
\hline Frequent & $\begin{array}{l}\text { It is probable that the risk will } \\
\text { occur frequently }\end{array}$ & Felt frequently \\
\hline Probable & $\begin{array}{l}\text { It will occur several times dur- } \\
\text { ing the life of an activity }\end{array}$ & Will occur often \\
\hline Occasional & $\begin{array}{l}\text { It will probably occur at some } \\
\text { time during the life of an item. }\end{array}$ & $\begin{array}{l}\text { Will occur sev- } \\
\text { eral times }\end{array}$ \\
\hline $\begin{array}{l}\text { Negligible, } \\
\text { rare }\end{array}$ & $\begin{array}{l}\text { It is not probable but is possible } \\
\text { that it will occur during the life } \\
\text { of an item. }\end{array}$ & $\begin{array}{l}\text { Not probable but } \\
\text { it is reasonable } \\
\text { to expect the } \\
\text { occurrence }\end{array}$ \\
\hline $\begin{array}{l}\text { Not prob- } \\
\text { able }\end{array}$ & $\begin{array}{l}\text { There is little probability to } \\
\text { suppose that the occurrence } \\
\text { might not be experienced. }\end{array}$ & $\begin{array}{l}\text { Not probable } \\
\text { to happen but } \\
\text { possible }\end{array}$ \\
\hline
\end{tabular}

Table 5. Defining probability of damage, injury occurrence.

Determining Risk Level. The connection between risk severity level and the frequency of its occurrence enables deter-

Table 3. How hazard affects the subject + injury/damage 
mining risk level. The levels are grouped into 4 categories (A, $\mathrm{B}, \mathrm{C}, \mathrm{D})$ where A risk level is the highest, while $\mathrm{D}$ is the lowest risk level. Risk levels enable ranking of risks, which contributes to more efficient planning of protection measures.

Risk Evaluation. Upon completing risk assessment, it is necessary to perform risk evaluation to determine whether risk reduction is needed or not. As regards the level, risks can be defined as unacceptable and as acceptable. Once it has been determined that risk is unacceptable, risk reduction is necessary by applying adequate protective measures. If risk is acceptable, no further risk analysis is needed. Level A risk always requires actions for risk reduction, while level D risk can be considered as acceptable risk and further risk analysis is not necessary. Levels $\mathrm{B}$ and $\mathrm{C}$ risks require some form of risk reduction, where organizational measures aimed at risk reduction are quite sufficient for level C risks.

\begin{tabular}{ccccc}
\hline \multirow{2}{*}{$\begin{array}{c}\text { Occurrence } \\
\text { Frequency }\end{array}$} & $\begin{array}{c}\text { Cata- } \\
\text { strophic }\end{array}$ & Severe & Small & Negligible \\
\hline Frequent & $\mathrm{A}$ & $\mathrm{A}$ & $\mathrm{A}$ & $\mathrm{C}$ \\
\hline Rare & $\mathrm{A}$ & $\mathrm{B}$ & $\mathrm{C}$ & $\mathrm{D}$ \\
\hline Improbable & $\mathrm{B}$ & $\mathrm{C}$ & $\mathrm{C}$ & $\mathrm{D}$ \\
\hline Rare & $\mathrm{A}$ & $\mathrm{B}$ & $\mathrm{C}$ & $\mathrm{D}$ \\
\hline
\end{tabular}

Table 6. Defining risk level.

Analysis of Risk Reduction Possibilities. Risk reduction can be achieved by reducing the hazards or damage severity from the hazard being considered and/or the probability of that damage occurrence. Protective measures intended for reaching this objective should be applied according to the so called threestep method given in standard EN ISO 12100.

\section{APPLICATION OF RISK ASSESSMENT METHODOLOGY IN MOBILE PHONE USE}

os, when children use the device, have higher occurrence probability so that the level of those risks is higher.

According to the conducted analysis, the very use of mobile phones by children is considered as highly risky, as the thin head bones in children and their skin and subcutaneous tissue do not present almost any obstacle for penetration of the harmful electromagnetic radiation.

One of the highest level risks of exposing the ears to loud sounds through mobile phone ear phones, which in some cases can bring about distraction of attention from the current user's activity and lead to major accident occurrence. There is also a great hazard from suffocating by small parts. The probability that very small children may put the device or its tiny parts in the mouth is very high. A high percentage of younger population using mobile devices glues adornment stickers on the devices or paints them or puts ornamentation masks on them. Adornment stickers and painting of the device may in some cases cause irritation of the user's skin, while the masks that are not allowed by the manufacturer can cause decreased acceptance/transfer of the signal which will cause the device to increase the broadcast strength, thus increasing the power of detrimental effect of the device's electromagnetic radiation. A high percentage of younger population using mobile devices glues adornment stickers on the devices or paints them or puts ornamentation masks on them. Adornment stickers and painting of the device may in some cases cause irritation of the user's skin, while the masks that are not allowed by the manufacturer can cause decreased acceptance/transfer of the signal, which will cause the device to increase the broadcast strength, thus increasing the power of detrimental effect of the device's electromagnetic radiation.

As protection of children on the Internet is currently one of the main and popular issues, it is something that should also be contemplated in this respect, considering the fact that mobile phones are actually small computers and most of them enable access to the Internet. Each action which leads to jeopardizing a child's safety should be considered as risk of the highest level.

\section{By applying the defined} assessment methodology, the risks have been assessed during mobile phone use by the risky group of users, i.e. by children. Eight hazards have been analyzed as they occur more often in mobile phone use by children than by adults. For each hazard observed, the type of injury/damage occurring on that occasion, and, on the basis of Tables 4 and 5, levels of injury/damage have been assessed, as well as the probability of injury/damage occurrence. On the basis of the data obtained in this manner, and on the basis of the risk level matrix defined in Table 6, risks levels have been determined. The estimated risk levels are shown in Table 7. The conducted analysis shows that certain harming prediction scenari-

\begin{tabular}{|c|c|c|c|c|c|}
\hline No & Typical injury inflicting scenario & Injury/Damage & $\begin{array}{l}\text { Injury/ } \\
\text { Damage } \\
\text { Level }\end{array}$ & $\begin{array}{l}\text { Injury/Damage } \\
\text { Occurrence } \\
\text { Probability }\end{array}$ & $\begin{array}{l}\text { Risk } \\
\text { Level }\end{array}$ \\
\hline \multirow{3}{*}{1} & \multirow{3}{*}{ The user bites or sucks the device or battery } & Device damage & 1 & Rare & $\mathrm{D}$ \\
\hline & & Explosion or fire & 3 & Not probable & $\mathrm{C}$ \\
\hline & & $\begin{array}{l}\text { Suffocation by small } \\
\text { parts }\end{array}$ & 4 & Rare & A \\
\hline \multirow[b]{2}{*}{2} & \multirow{2}{*}{$\begin{array}{l}\text { The user puts the device or delivered ad- } \\
\text { ditional kit into eyes, mouth or ears }\end{array}$} & Suffocation & 4 & Rare & A \\
\hline & & $\begin{array}{l}\text { Serious eyesight and } \\
\text { hearing injuries }\end{array}$ & 3 & Rare & B \\
\hline \multirow{2}{*}{3} & \multirow{2}{*}{$\begin{array}{l}\text { The user uses flashlight or camera light near } \\
\text { the eyes of people or pats }\end{array}$} & Temporary eyesight loss & 1 & Occasional & $\mathrm{D}$ \\
\hline & & Damage to eyes & 2 & Rare & $\mathrm{C}$ \\
\hline 4 & $\begin{array}{l}\text { The user is exposed in a long period of time } \\
\text { to the flickering light from the device screen }\end{array}$ & $\begin{array}{l}\text { Fainting, eye muscles } \\
\text { cramps, disorientation }\end{array}$ & 1 & Occasional & $\mathrm{D}$ \\
\hline \multirow[b]{2}{*}{5} & \multirow[b]{2}{*}{$\begin{array}{l}\text { The user exposes his/her ears to loud sounds } \\
\text { in the course of using device earphones }\end{array}$} & Hearing damage & 2 & Occasional & B \\
\hline & & $\begin{array}{l}\text { Accidents caused by dis- } \\
\text { tracting attention from } \\
\text { current activity }\end{array}$ & 4 & Rare & A \\
\hline \multirow[b]{2}{*}{6} & \multirow{2}{*}{$\begin{array}{l}\text { The user paints the device or puts stickers } \\
\text { to it }\end{array}$} & Device malfunctioning & 1 & Probable & $\mathrm{C}$ \\
\hline & & $\begin{array}{l}\text { Rash, eczema or skin } \\
\text { irritation }\end{array}$ & 2 & Occasional & $\mathrm{B}$ \\
\hline \multirow[b]{2}{*}{7} & \multirow{2}{*}{$\begin{array}{l}\text { The user takes over unfamiliar applica- } \\
\text { tions, visits unreliable web locations, does } \\
\text { not delete dubious messages or e-messages } \\
\text { from unknown senders, does not change the } \\
\text { password regularly etc. }\end{array}$} & Data damage or loss & 1 & Probable & $\mathrm{C}$ \\
\hline & & $\begin{array}{l}\text { Jeopardizing children's } \\
\text { safety, electronic violence }\end{array}$ & 3 & Occasional & A \\
\hline \multirow{2}{*}{8} & \multirow{2}{*}{$\begin{array}{l}\text { The user using mobile phone is less than } 10 \\
\text { years old, which directly implies increased } \\
\text { effects of detrimental EM radiation }\end{array}$} & Insomnia, headache & 2 & Probable & $\mathrm{B}$ \\
\hline & & Brain cancer & 4 & Rare & A \\
\hline
\end{tabular}

Table 7. Estimate of level of most frequent risks occurring during mobile phone use by children 
In accordance with the risk reduction methodology of the New Approach directives given in standard EN ISO 12100, contribution is also expected from the designer as well as from the user of the device. Possible measures aimed at risk reduction during mobile phone use by children can be divided into several categories, depending on the person/organization which is carrying them out. By implementing adequate measures, contribution to risk reduction can be provided by equipment manufacturers, state authorities, Internet providers and mobile telecommunication distributors, parents, experts dealing with children, media.

\section{CONCLUSION}

The subject of this paper is to define the adequate methodology for the assessment of the risks in mobile phone use, which represents a type of R\&TT equipment. By referring to relevant and realistic facts, measurements and research, this paper indicates the consequences that can occur in using the R\&TT equipment, primarily for mobile phone use. In analyzing the consequences that can occur, the emphasis is placed on the most jeopardized user category, i.e. the children. When observed from several different points of view, the usage of mobile phones by children is utterly unnecessary and potentially risky. By applying the defined methodology, high level risks have been assessed, such as detrimental electromagnetic radiation and exploitation of children by ICT.

It is expected that the methodology proposed in this paper, and research results on harmful effects of mobile phone use, will contribute to raising the awareness of experts and wider public with respect to the need for all relevant social protagonists to get involved in suppressing and preventing the harmful effects. What is certainly necessary is to improve the legal framework, strengthen capacities and coordinate cooperation between experts and competent institutions and increase the awareness of experts and wider public regarding the forms, causes and the long-term, socially disastrous consequences of mobile phone use, with the aim to protect the overall health and safety of children and other users.

\section{LITERATURE}

Bašić, A., \& Popović, P. (2013). Analysis of the implementation of RTTE Directive in the tehnical legislation of the Republic of Serbia. In: DQM International Conference on Life Cycle Engineering and Management. (3-10). Čačak: Research Center DQM.

Bašić, A., \& Popović, P. (2014). Risk assessment procedures for products which do not fulfill the essential requirements of RTTE directive. In: SINTEZA. (907-913). Belgrade: Singidunum University

Bašić, A., Viduka, D. (2014). Harmful effects of mobile phone use amongst children. Bizinfo. 5(2), 1-14.

Bhat, M.A., Kumar, V., \& Gupta, G.K. (2013). Effect of mobile phone and mobile phone tower radiations of human health. International Journal of Recent Scientific Research. 4 (9), 1422-1426.

Dragin, A. (2013). Child exploitation on the Internet: The research report of the Provincial Ombudsman. Novi Sad: Provincial Ombudsman.

Đapić, M., Popović, P., Lukić, Lj., \& Mitrović R. (2012). Risk Assessment Concept in the New Approach Directives and its integration in the Enterprise Risk Management (ERM). Industrija. 40, 3-38.

ISO. (2010). ISO 12100: 2010 -Safety of machinery-Generaly principles for design - Risk assessment and risk reduction. International Organization for Standardization, www.iso.org

Krstić, D., Marković, V., \& Nikolić, N. (2004). Biological effects of radiation wireless communication systems. Acta Medica Medianae, 43(4), 55-63.

Kumar, V., Ahmad, M., \& Sharma, A.K. (2010). Harmfuleffect of mobile phone waves on blood tissues of the human body. Eastern Journal of Medicine. 15, 80-89.

The use of information and communication technologies in the Republic of Serbia. (2013). Republic Institute for Statistics, Republic of Serbia. 